Prepared in cooperation with the Charles County Government and the

Port Tobacco River Conservancy, Inc.

\title{
Summary of Organic Wastewater Compounds and Other Water-Quality Data in Charles County, Maryland, October 2007 through August 2008
}

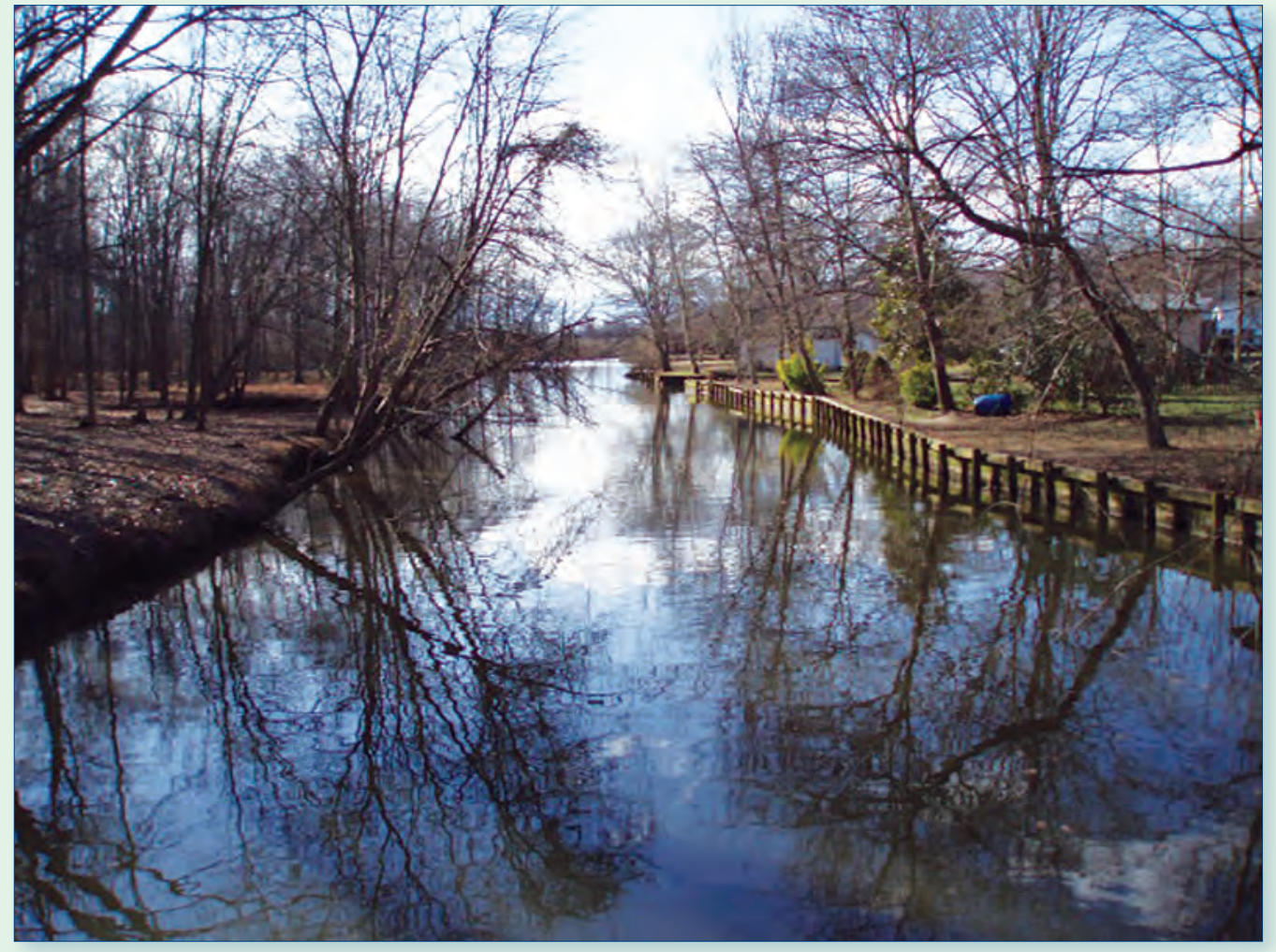

Open-File Report 2010-1071 
Cover. Photograph of the tidal section of Port Tobacco River in the Hoghole Run subwatershed, Charles County, Maryland. 


\section{Summary of Organic Wastewater Compounds and Other Water-Quality Data in Charles County, Maryland, October 2007 through August 2008}

By Michelle M. Lorah, Daniel J. Soeder', and Jessica A. Teunis

${ }^{1}$ U.S. Department of Energy, formerly of the U.S. Geological Survey

Prepared in cooperation with the

Charles County Government and the

Port Tobacco River Conservancy, Inc.

Open-File Report 2010-1071 


\section{U.S. Department of the Interior \\ KEN SALAZAR, Secretary \\ U.S. Geological Survey \\ Marcia K. McNutt, Director}

U.S. Geological Survey, Reston, Virginia: 2010

For more information on the USGS - the Federal source for science about the Earth, its natural and living resources, natural hazards, and the environment, visit http://www.usgs.gov or call 1-888-ASK-USGS

For an overview of USGS information products, including maps, imagery, and publications, visit http://www.usgs.gov/pubprod

To order this and other USGS information products, visit http://store.usgs.gov

Any use of trade, product, or firm names is for descriptive purposes only and does not imply endorsement by the U.S. Government.

Although this report is in the public domain, permission must be secured from the individual copyright owners to reproduce any copyrighted materials contained within this report.

Suggested citation:

Lorah, M.M., Soeder, D.J., and Teunis, J.A., 2010, Summary of organic wastewater compounds and other water-quality data in Charles County, Maryland, October 2007 through August 2008: U.S. Geological Survey Open-File Report 2010-1071, 19 p., plus appendixes (online). 


\section{Contents}

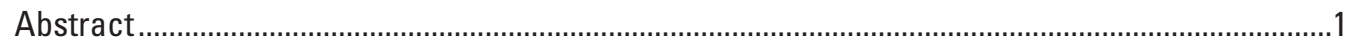

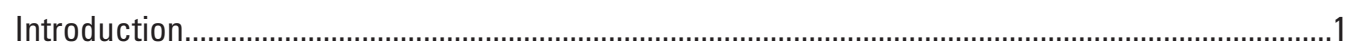

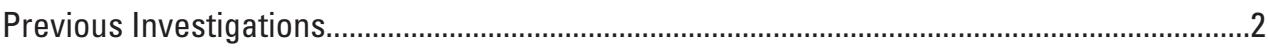

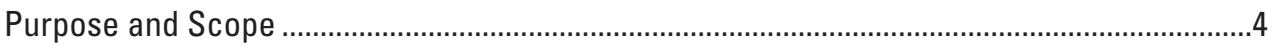

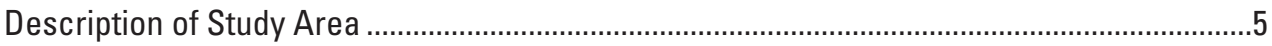

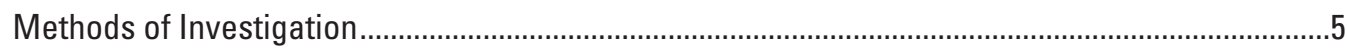

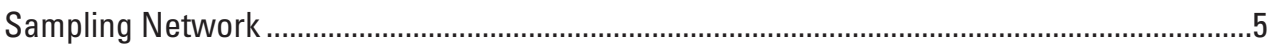

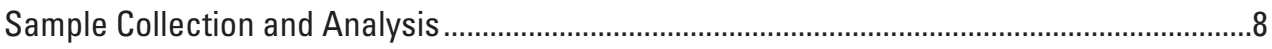

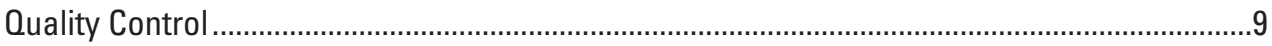

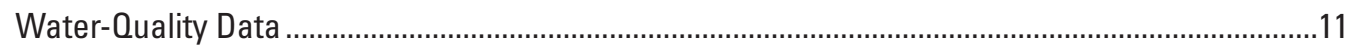

Field Parameters and Major and Minor Inorganic Constituents ............................................11

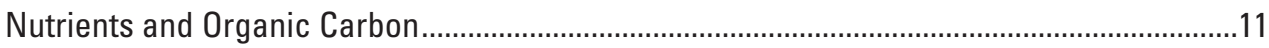

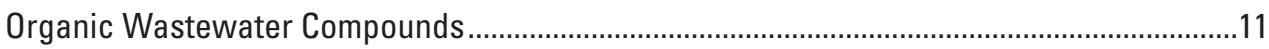

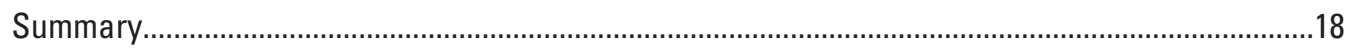

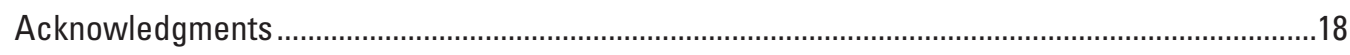

References Cited................................................................................................................. 18

Appendix 1. Water-Quality Data from Phase 1 Sampling......................................... available online

$1 \mathrm{~A}$. Field parameters and inorganic constituents measured in groundwater, porewater, and surface-water samples,

Port Tobacco River and Nanjemoy Creek watersheds, Charles County, Maryland, October 9 and 30, 2007 (Phase1)

1B. Organic wastewater compounds detected in groundwater, porewater, and surface-water grab samples, Port Tobacco River and Nanjemoy Creek watersheds, Charles County, Maryland, October 9 and 30, 2007 (Phase 1)

Appendix 2. Water-Quality Data from Phase 2 Sampling. available online

2A. Field parameters and inorganic constituents measured in groundwater, porewater, and surface-water grab samples, Port Tobacco River and Nanjemoy Creek watersheds, Charles County, Maryland, June-July 2008 (Phase 2)

2B. Organic wastewater compounds detected in groundwater, porewater, and surface-water samples, Port Tobacco River and Nanjemoy Creek Watersheds, Charles County, Maryland, June-July 2008 (Phase 2)

2C. Organic wastewater compounds detected in Polar Organic Chemical Integrative Samplers (POCISs), Port Tobacco River watershed, Charles County, Maryland, July 23-August 21, 2008

Appendix 3. Comparison of type and number of organic wastewater compounds that were detected in groundwater, porewater, and surface-water grab samples, and in Polar Organic Chemical Integrative Sampler (POCIS) samples collected in the Port Tobacco River and Nanjemoy Creek watersheds, Charles County, Maryland, 2007 through 2008 (Phases 1 and 2) ... available online 


\section{Figures}

1-3. Maps showing-

1. Location of the Nanjemoy Creek and Port Tobacco River watershed study areas in Charles County, Maryland

2. Locations of U.S. Geological Survey surface-water-sampling sites in the Nanjemoy Creek and Port Tobacco River watersheds, Charles County, Maryland

3. Satellite image of U.S. Geological Survey wells installed for groundwater or porewater sampling at Port Tobacco Riviera in Charles County, Maryland

\section{Tables}

1. Summary of sample locations, dates, and types, Charles County,

Maryland, 2007 through 2008

2. Sample collection and treatment for analysis by the U.S. Geological

Survey National Water Quality Laboratory

3. Concentrations of inorganic constituents and organic carbon detected in field blank samples during Phase 1 and Phase 2 sampling events, Charles County, Maryland, 2007 through 2008

4. Relative percent difference (RPD) between duplicate samples collected for field parameters, inorganic constituents, and organic carbon during Phase 1 and Phase 2 sampling, Charles County, Maryland, 2007 through 2008

5. Potential uses or sources of organic wastewater compounds that were detected in groundwater and surface-water grab samples and in Polar Organic Chemical Integrative Sampler (POCIS) samples, Port Tobacco River and Nanjemoy Creek watersheds, Charles County, Maryland, 2007 through 2008

6. Organic wastewater compounds that were analyzed but not detected in groundwater and surface-water grab samples, or in Polar Organic Chemical Integrative Sampler (POCIS) samples collected in the Port Tobacco River and Nanjemoy Creek watersheds, Charles County, Maryland, 2007 through 2008

7. Organic wastewater compounds detected in field blank samples during Phase 1 and Phase 2 sampling events, Charles Charles County, Maryland, 2007 through 2008

8. Relative percent difference (RPD) between duplicate samples collected for organic wastewater compounds during Phase 1 and Phase 2 sampling, Charles County, Maryland, 2007 through 2008 


\section{Conversion Factors and Datums}

\begin{tabular}{lcl}
\hline Multiply & By & To obtain \\
\hline & Length & \\
\hline inch (in.) & 2.54 & centimeter \\
inch (in.) & 25.4 & millimeter \\
foot (ft) & 0.3048 & meter \\
\hline \multicolumn{3}{c}{ Volume } \\
\hline gallon (gal) & 3.785 & liter (L) \\
\hline
\end{tabular}

Temperature in degrees Celsius $\left({ }^{\circ} \mathrm{C}\right)$ may be converted to degrees Fahrenheit $\left({ }^{\circ} \mathrm{F}\right)$ as follows:

$$
{ }^{\circ} \mathrm{F}=1.8\left({ }^{\circ} \mathrm{C}\right)+32
$$

Temperature in degrees Fahrenheit $\left({ }^{\circ} \mathrm{F}\right)$ may be converted to degrees Celsius $\left({ }^{\circ} \mathrm{C}\right)$ as follows:

$$
{ }^{\circ} \mathrm{C}=\left({ }^{\circ} \mathrm{F}-32\right) / 1.8
$$

Vertical coordinate information is referenced to the North American Vertical Datum of 1988 (NAVD 88). Horizontal coordinate information is referenced to the North American Datum of 1983 (NAD 83). Altitude, as used in this report, refers to distance above the vertical datum. Specific conductance is given in microsiemens per centimeter at 25 degrees Celsius $\left(\mu \mathrm{S} / \mathrm{cm}\right.$ at $\left.25^{\circ} \mathrm{C}\right)$. Concentrations of chemical constituents in water are given either in milligrams per liter ( $\mathrm{mg} / \mathrm{L}$ ) or micrograms per liter $(\mu \mathrm{g} / \mathrm{L})$. 



\title{
Summary of Organic Wastewater Compounds and Other Water-Quality Data in Charles County, Maryland, October 2007 through August 2008
}

\author{
By Michelle M. Lorah, Daniel J. Soeder, and Jessica A. Teunis
}

\begin{abstract}
The U.S. Geological Survey, in cooperation with the government of Charles County, Maryland, and the Port Tobacco River Conservancy, Inc., conducted a water-quality reconnaissance and sampling investigation of the Port Tobacco River and Nanjemoy Creek watersheds in Charles County during October 2007 and June-August 2008. Samples were collected and analyzed for major ions, nutrients, organic wastewater compounds, and other selected constituents from 17 surfacewater sites and 11 well sites (5 of which were screened in streambed sediments to obtain porewater samples). Most of the surface-water sites were relatively widely spaced throughout the Port Tobacco River and Nanjemoy Creek watersheds, although the well sites and some associated surface-water sites were concentrated in one residential community along the Port Tobacco River that has domestic septic systems. Sampling for enterococci bacteria was conducted by the Port Tobacco River Conservancy, Inc., at each site to coordinate with the sampling for chemical constituents. The purpose of the coordinated sampling was to determine correlations between historically high, in-stream bacteria counts and human wastewater inputs. Chemical data for the groundwater, porewater, and surfacewater samples are presented in this report.
\end{abstract}

\section{Introduction}

Moderate to high levels of bacteria and nutrients from potential anthropogenic sources have been detected in a number of streams and rivers in Charles County, Maryland, including the Port Tobacco River and Nanjemoy Creek watersheds (fig. 1). Septic system failure in seven major residential areas in the northern part of the Port Tobacco River watershed has been identified as a major potential source of nutrients, bacteria, and other contaminants to the surface water (Port Tobacco River Conservancy, Inc., 2008). The Nanjemoy Creek watershed, however, is less populated and largely forested. A high rate of septic system failure in the Port Tobacco River watershed is known or suspected on the basis of a study conducted by the Port Tobacco River Conservancy, Inc. (PTRC) (Port Tobacco River Conservancy, Inc., 2008). The U.S. Geological Survey (USGS), in cooperation with the government of Charles County, Maryland and the PTRC, collected water-quality samples from 17 surface-water sites and 11 well sites in Charles County in October 2007 and June-August 2008. Surface-water, groundwater, and porewater (the water in shallow streambed sediments that can be a mixture of surface water and groundwater; also called hyporheic zone water) samples were collected and analyzed to provide data that could be used to better define the sources and factors controlling the occurrence of contaminants to streams in the Port Tobacco River and Nanjemoy Creek watersheds. Surface-water quality can be affected by point sources (such as wastewater treatment plant outfalls) and nonpoint source contamination within a watershed, which can be transported to streams by overland runoff, groundwater discharge, or upstream tributaries (Ator and others, 2005). Sampling of both surface water and porewater at selected locations was done to assist in distinguishing between groundwater discharge and runoff or point source surface-water inputs.

Surface-water samples were collected at locations relatively widely dispersed throughout both watersheds, whereas the groundwater and porewater sampling was focused near selected surface-water sites in one residential area near the Port Tobacco River (fig. 2). This residential area, known as the Port Tobacco Riviera, contains several dozen single family residences with domestic wells and septic systems, and a marina and trailer park campground that also have septic systems (fig. 3). Samples were collected and analyzed for major ions, nutrients, and organic wastewater compounds (OWCs). The OWC analytical method provides a suite of 69 chemical constituents that include prescription and non-prescription drugs, fragrances and flavorings, cosmetics, flame retardants, plasticizers, detergents and metabolites, disinfectants, 


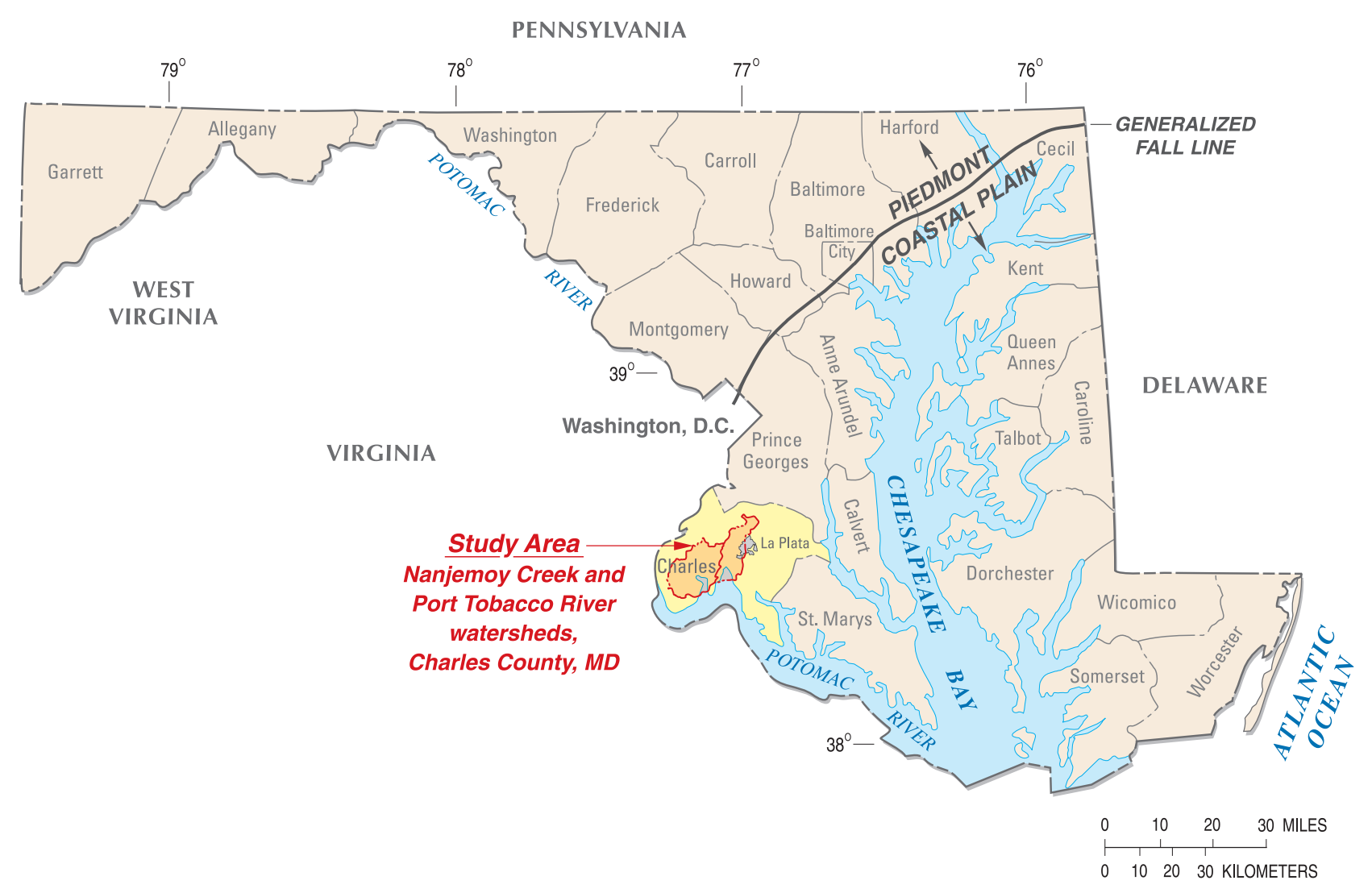

Figure 1. Location of the Nanjemoy Creek and Port Tobacco River watershed study areas in Charles County, Maryland.

pesticides, and combustion products (Zaugg and others, 2006). The USGS sampling activity was coordinated with sampling for enterococci bacteria that was conducted by the PTRC. The intent of the coordinated sampling was to determine whether high bacterial counts might correlate to high levels of nutrients and (or) different OWCs that could assist in distinguishing between possible anthropogenic sources, such as wastewater treatment plant outfalls, leaking septic systems, or wildlife or pet waste.

\section{Previous Investigations}

The Charles County Department of Health, the PTRC, and the Nanjemoy Conservancy have been sampling surface water at approximately 40 locations in the Port Tobacco River watershed since May 2003, and approximately 13 locations in the adjacent Nanjemoy Creek watershed since June 2006. Enterococci bacteria were found to exceed 4,020 colonies/100 $\mathrm{mL}$ (milliliters) in October 2005 at several locations in the Port Tobacco River watershed. The highest concentration of the enterococci bacteria in the Nanjemoy Creek watershed was 1,650 colonies/100 mL in August 2006 (Port Tobacco River Conservancy, Inc., 2008).
Recent studies have shown that the widespread occurrence of OWCs in streams, including cleaning products and chemical surfactants, personal-care products, flame retardants, steroids, pesticides, hormones, pharmaceuticals, and antibiotics, are presumably introduced from human wastewater (Kolpin and others, 2002; Erickson, 2002; Hyer, 2007; Tertuliani and others, 2008). Evidence indicates that these chemicals can affect in-stream biota: a USGS investigation on the South Branch of the Potomac River in West Virginia observed that up to 79 percent of male bass had evidence of intersex, including the development of eggs in male gonads (Vicki Blazer, USGS, oral commun., 2007), and a recent study by the USGS in Washington, D.C. found compromised fish health in Rock Creek, including evidence of unsuccessful spawning of white sucker (Miller and others, 2006). These and other recent fish-health studies have greatly increased the concern of the public and government agencies over the occurrence of anthropogenic compounds in local water bodies, especially streams that are used for drinking-water supply. Potential sources of these chemicals include runoff from livestock facilities, pet wastes, leaking septic and sewer infrastructure, combined sewer outfalls, and effluent from treated wastewater, all of which are present in Charles County, Maryland. 


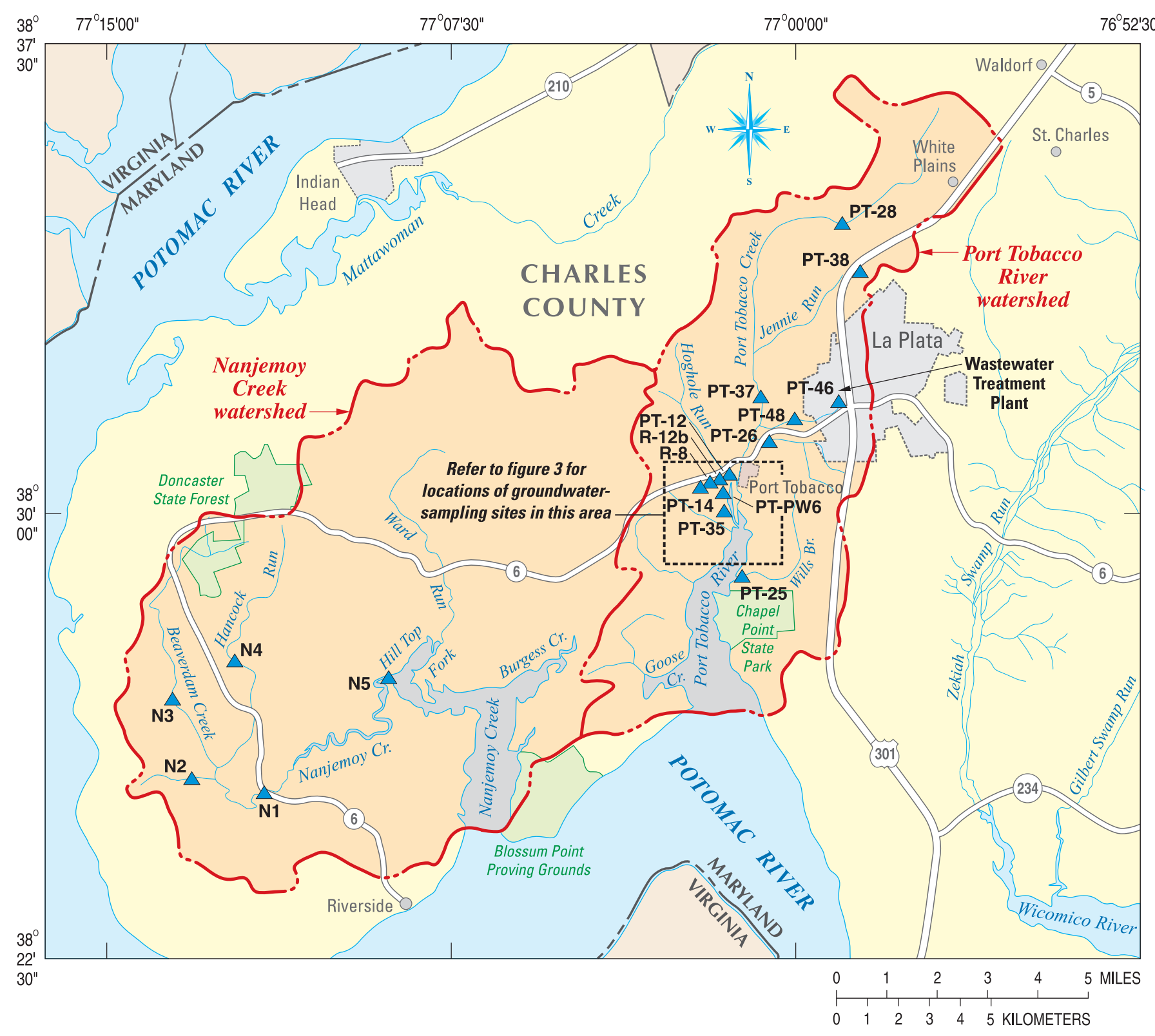

EXPLANATION

PT-25 $\triangle$ SURFACE-WATER SAMPLING SITE AND IDENTIFICATION NUMBER

Figure 2. Locations of U.S. Geological Survey surface-water sampling sites in the Nanjemoy Creek and Port Tobacco River watersheds, Charles County, Maryland. 


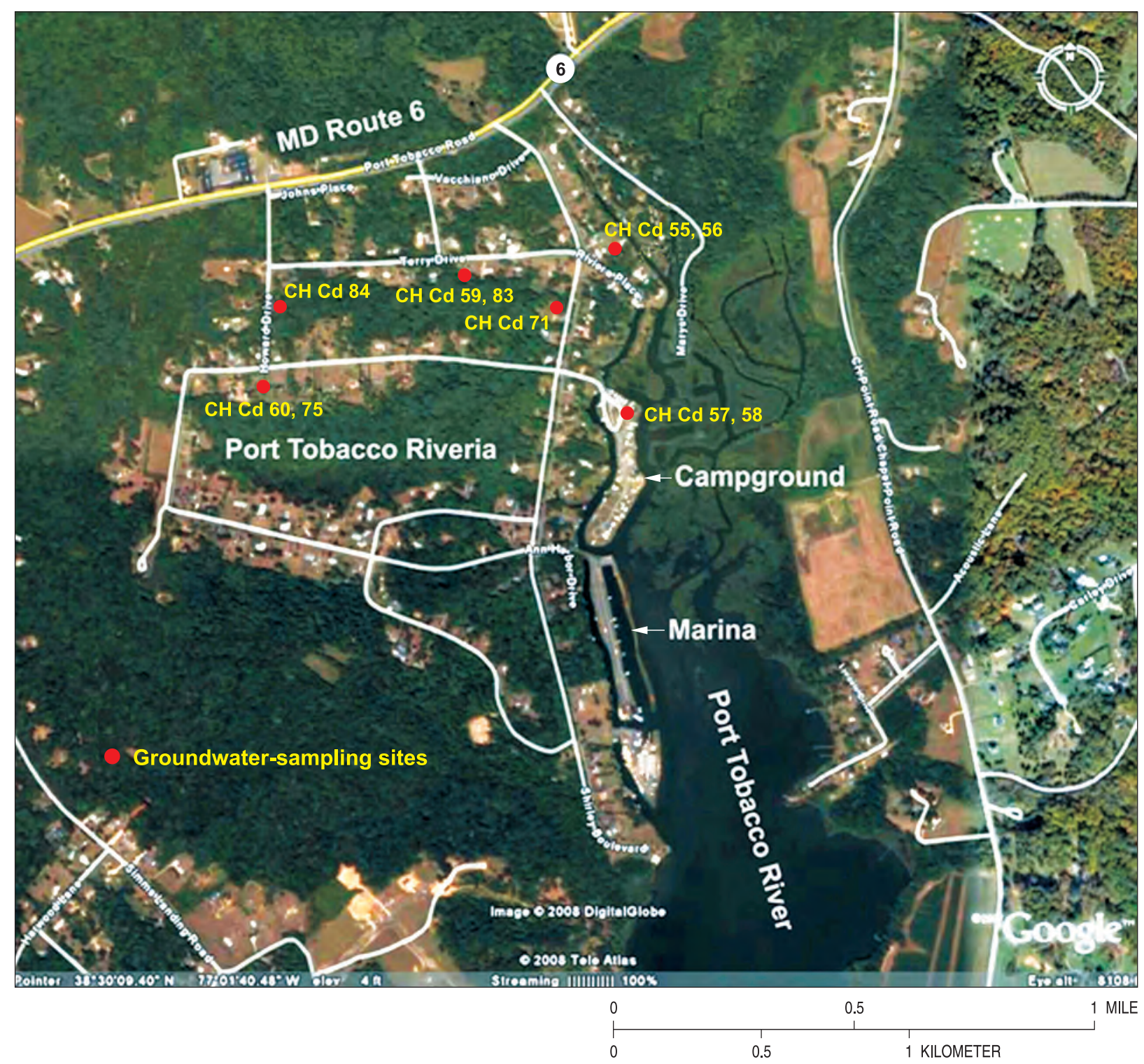

Figure 3. Satellite image of U.S. Geological Survey wells installed for groundwater or porewater sampling at Port Tobacco Riviera in Charles County, Maryland.

\section{Purpose and Scope}

The purpose of this report is to present water-quality chemical data collected by USGS in Charles County, Maryland to provide guidance for future sampling efforts to determine the possible sources of enterococci bacteria. Samples were collected on a local scale within the Port Tobacco Riviera community to investigate the effect of shallow groundwater transport from residential septic fields on surface-water quality, and on a watershed scale in the Port Tobacco River and Nanjemoy Creek watersheds to provide additional water-quality data at sites that historically have had elevated enterococci levels.
Analytical results from a total of 17 surface-water sites and 11 wells (5 of which were screened in streambed sediments to obtain porewater samples) are presented in this report. Samples were collected in October 2007 (Phase 1) and June through August 2008 (Phase 2) and analyzed for major ions, nutrients, OWCs, and other selected constituents. Phase 2 sampling included fewer surface-water sites than those sampled in Phase 1, but had a greater focus on porewater and groundwater sampling associated with the surface-water sampling. Porewater data include samples collected either from shallow wells or by passive diffusion sampling techniques, including dialysis bags for inorganic constituents and Polar Organic Chemical Integrative Samplers (POCISs) for OWCs. 
The data also include analyses of a total of five replicate samples (each corresponding to one of the environmental samples) and four field equipment blanks collected for quality control. This report describes the site selection, sampling bias, and sample collection and analysis methods, in addition to presenting the analytical results.

\section{Description of Study Area}

The study area is in southern Maryland on the Atlantic Coastal Plain (fig. 1). The Port Tobacco River and Nanjemoy Creek are in neighboring watersheds in southwestern Charles County, and both flow southward into the tidal Potomac River. The terrain consists of hilly upland areas that reach elevations of up to about 200 feet, dropping down to flat, lowland areas near the Potomac River that are close to sea level. Drainage in the study area watersheds is dendritic in the upland areas, where small tributaries confined to incised valleys join and feed the main streams. The middle and lower reaches of the main-stem streams are located in flat-bottomed valleys, with broad flood plains, meandering channels, and occasional swampy or marshy areas. The lower tidal reaches of the streams consist of wide, shallow, water-filled channels.

Surface deposits are composed of Tertiary and Quaternary-age sands and gravels in the upland areas, and finer Quaternary sediments in the lowlands (McCartan, 1989). Subsurface sedimentary units include the Calvert Formation and the underlying Nanjemoy Formation, named by Clark and Martin (1901) for exposures in bluffs along Nanjemoy Creek in the study area. The Calvert and Nanjemoy Formations together form an important Coastal Plain aquifer; the base of the Nanjemoy Formation grades downward into a lowpermeability, confining unit known as the Marlboro Clay (McCartan, 1989). Groundwater seepage into streams in the two watersheds comes from sedimentary units located above this clay, including the Nanjemoy and Calvert Formations, and also from surficial Quaternary sediments (Krantz and Powars, 2000).

Population centers in the study area consist mostly of rural, small towns and scattered developments. The largest city within the boundaries of the two watersheds is La Plata, with a population estimated at 8,739 in 2006 (U.S. Census Bureau, 2008). Most of the non-urban, rural population uses individual domestic or community wells for water supply, along with septic systems for wastewater disposal. The town of La Plata receives its water supply from deep municipal wells that withdraw from the confined upper and lower Patapsco aquifers (Soeder and others, 2007). La Plata wastewater is treated at a plant located near the intersection of Routes 6 and 301, and the effluent is released into a small, unnamed tributary of the Port Tobacco River (fig. 2). A second, smaller wastewater treatment plant servicing the College of Southern Maryland at Mt. Carmel Woods has an outfall on the main stem of the Port Tobacco River. No wastewater treatment plants are located within the Nanjemoy Creek watershed.

\section{Methods of Investigation}

The USGS collected water-quality samples from Charles County, Maryland on October 9 and October 30, 2007 for Phase 1 sampling events and from June through August 2008 for Phase 2 sampling events (table 1). Surface-water, groundwater, and porewater samples were collected; porewater samples were obtained using either wells or passive diffusion sampling techniques that are described in the Sampling Network section.

\section{Sampling Network}

For Phase 1, sampling locations included 10 surfacewater sites within the Port Tobacco River watershed, 5 surface-water sites within the Nanjemoy Creek watershed, 4 groundwater wells, and 2 porewater wells located in the Port Tobacco Riviera community (fig. 2 and table 1). Each location was assigned a unique USGS site number based on its latitude and longitude and is also identified with a local site name (table 1). Designation of local site names for groundwater wells follows the grid-system convention of the Maryland Geological Survey, which is described in the introductory section of the USGS MD-DE-DC Groundwater Annual Data Report (Curtin and others, 2006). Local site names for surface-water sites that were previously sampled for bacteria by the Charles County Department of Health and the PTRC are identified with the same local site name. Passive diffusion samplers (dialysis bags or POCISs) are identified with the same local site name as the well or surface-water site at which they were placed, whereas the field name also indicates the sample type (table 1).

The groundwater wells were installed by USGS in July 2007 using a direct-push rig and consist of 1-in. (inch)diameter polyvinyl chloride (PVC) pipe with 1-ft (foot)-long screened intervals. The porewater wells also were 1-in.-diameter PVC with 1-ft-long screens and were driven manually into the streambed near selected well sites. After reconnaissance sampling was completed by the USGS in May 2007 (data on file, USGS MD-DE-DC office, Baltimore, Maryland), groundwater and porewater sites were selected to provide data along one of the intermittent streams that run through ravines toward the Port Tobacco River, in addition to data adjacent to (or in) the Port Tobacco River (fig. 3). Surface-water sites were located either near USGS well sites or at sites sampled previously by PTRC for bacteria. For Phase 2, one sampling event was conducted on June 3-4, 2008 that focused primarily on groundwater and streambed porewater sampling in the Port Tobacco Riviera community, whereas a second sampling event that began on July 29, 2008 focused on resampling selected surface-water sites in the Port Tobacco River and Nanjemoy Creek watersheds that had been sampled in Phase 1. Dialysis bag and POCIS porewater sampling was paired with this surface-water sample collection (figs. 2 and 3; table 1). 
Table 1. Summary of sample locations, dates, and types, Charles County, Maryland, 2007 through 2008.

[PT, Port Tobacco; Riviera, Port Tobacco Riviera community; NC, Nanjemoy Creek; WWTP, wastewater treatment plant; --, not applicable; GW, groundwater; PW, porewater; SW, surface water; POCIS, Polar Organic Chemical Integrative Sampler; D/P, dialysis and POCIS]

\begin{tabular}{|c|c|c|c|c|c|c|c|}
\hline $\begin{array}{c}\text { U.S. Geological } \\
\text { Survey site } \\
\text { identification } \\
\text { number }\end{array}$ & Sample dates $^{1}$ & $\begin{array}{l}\text { Local site } \\
\text { name }\end{array}$ & $\begin{array}{l}\text { Sample } \\
\text { type }\end{array}$ & Field name & Watershed & $\begin{array}{l}\text { Screen } \\
\text { or } \\
\text { sampler } \\
\text { depth } \\
\text { (feet) }\end{array}$ & $\begin{array}{c}\text { Location } \\
\text { description }\end{array}$ \\
\hline \multicolumn{8}{|c|}{ Phase 1} \\
\hline 383027077013201 & $10 / 9 / 2007$ & $\mathrm{CH}$ Cd 55 & GW Well & PT-Z1A & PT/Riviera & $8.0-9.0$ & 8240 Riviera Place \\
\hline 383009077013401 & $10 / 9 / 2007$ & CH Cd 57 & GW Well & PT-Z4A & PT/Riviera & $20-21$ & $\begin{array}{l}\text { RV Campground lot } \\
\quad 25\end{array}$ \\
\hline 383009077013402 & $10 / 9 / 2007$ & $\mathrm{CHCd} 58$ & PW Well & PT-PW4 & PT/Riviera & $2.0-3.0$ & $\begin{array}{l}\text { RV Campground lot } \\
\quad 25\end{array}$ \\
\hline 383026077015001 & $10 / 9 / 2007$ & $\mathrm{CH}$ Cd 59 & GW Well & PT-Z5A & PT/Riviera & $7.0-8.0$ & 8009 Terry Drive \\
\hline 383027077013204 & $10 / 30 / 2007$ & PT-12 & SW Grab & PT-12 & PT/Riviera & -- & 8240 Riviera Place \\
\hline 383043077014201 & $10 / 30 / 2007$ & PT-14 & SW Grab & PT-14 & PT & -- & $\begin{array}{l}\text { Hog Hole Run/Route } \\
6\end{array}$ \\
\hline 382857077005801 & $10 / 30 / 2007$ & PT-25 & SW Grab & PT-25 & $\mathrm{PT}$ & -- & Will's Branch \\
\hline 383115077005001 & $10 / 30 / 2007$ & PT-26 & SW Grab & PT-26 & PT & -- & Route 6 , South side \\
\hline 383455076591301 & $10 / 30 / 2007$ & PT-28 & SW Grab & PT-28 & $\mathrm{PT}$ & -- & $\begin{array}{l}\text { PT Creek, Turkey Hill } \\
\text { Road }\end{array}$ \\
\hline 383009077013404 & $10 / 30 / 2007$ & PT-35 & SW Grab & PT-35 & PT & -- & $\begin{array}{l}\text { RV Campground lot } \\
\quad 25\end{array}$ \\
\hline 383156077005401 & $10 / 30 / 2007$ & PT-37 & SW Grab & PT-37 & PT & -- & $\begin{array}{l}6485 \text { Warren Eller } \\
\text { Drive }\end{array}$ \\
\hline 383133077002501 & $10 / 30 / 2007$ & PT-48 & SW Grab & PT-48 & $\mathrm{PT}$ & -- & Darly Drive \\
\hline 382514077115301 & $10 / 9 / 2007$ & $\mathrm{~N}-1$ & SW Grab & $\mathrm{N}-1$ & $\mathrm{NC}$ & -- & $\begin{array}{l}\text { Bucky's-Trappe } \\
\text { Bridge }\end{array}$ \\
\hline 382522077124801 & $10 / 9 / 2007$ & $\mathrm{~N}-2$ & SW Grab & $\mathrm{N}-2$ & $\mathrm{NC}$ & -- & Hancock Run \\
\hline 382713077134601 & $10 / 9 / 2007$ & $\mathrm{~N}-3$ & SW Grab & $\mathrm{N}-3$ & $\mathrm{NC}$ & -- & Willets Run \\
\hline 382727077122301 & $10 / 9 / 2007$ & $\mathrm{~N}-4$ & SW Grab & $\mathrm{N}-4$ & $\mathrm{NC}$ & -- & Baptist Church Run \\
\hline 382714077090201 & $10 / 9 / 2007$ & $\mathrm{~N}-5$ & SW Grab & $\mathrm{N}-5$ & $\mathrm{NC}$ & -- & Friendship Landing \\
\hline
\end{tabular}


Table 1. Summary of sample locations, dates, and types, Charles County, Maryland, 2007 through 2008.-Continued

[PT, Port Tobacco; Riviera, Port Tobacco Riviera community; NC, Nanjemoy Creek; WWTP, wastewater treatment plant; --, not applicable; GW, groundwater; PW, porewater; SW, surface water; POCIS, Polar Organic Chemical Integrative Sampler; D/P, dialysis and POCIS]

\begin{tabular}{|c|c|c|c|c|c|c|c|}
\hline $\begin{array}{l}\text { U.S. Geological } \\
\text { Survey site } \\
\text { identification } \\
\text { number }\end{array}$ & Sample dates $^{1}$ & $\begin{array}{l}\text { Local site } \\
\text { name }\end{array}$ & $\begin{array}{l}\text { Sample } \\
\text { type }\end{array}$ & Field name & Watershed & $\begin{array}{l}\text { Screen } \\
\text { or } \\
\text { sampler } \\
\text { depth } \\
\text { (feet) }\end{array}$ & $\begin{array}{l}\text { Location } \\
\text { description }\end{array}$ \\
\hline \multicolumn{8}{|c|}{ Phase 2} \\
\hline 383027077013101 & $6 / 4 / 2008$ & $\mathrm{CH} \mathrm{Cd} 56$ & PW Well & PT-PW1 (well) & PT/Riviera & $1.0-2.0$ & 8240 Riviera Place \\
\hline 383026077014702 & $6 / 3 / 2008$ & $\mathrm{CH} \mathrm{Cd} 83$ & PW Well & PT-PW5 (well) & PT/Riviera & $1.0-2.0$ & creek near PT-Z5 \\
\hline 383026077014702 & $6 / 4 / 2008$ & $\mathrm{CH} \mathrm{Cd} 83$ & PW Well & PT-PW5 (well) & PT/Riviera & $1.0-2.0$ & creek near PT-Z5 \\
\hline 383025077014202 & $6 / 4 / 2008$ & $\mathrm{CH}$ Cd 71 & GW Well & PT-Z6B & PT/Riviera & $8.5-9.5$ & $\begin{array}{r}7455 \text { Shirley } \\
\text { Boulevard }\end{array}$ \\
\hline no number assigned & $6 / 4 / 2008$ & -- & PW Well & PT-PW6 (well) & PT/Riviera & $1.0-2.0$ & creek near PT-Z6 \\
\hline 383023077021201 & $6 / 4 / 2008$ & $\mathrm{CH} \mathrm{Cd} 84$ & PW Well & PT-PW8 (well) & PT/Riviera & $1.0-2.0$ & creek near PT-Z8 \\
\hline 383023077021202 & $6 / 3 / 2008$ & $\mathrm{R}-8$ & SW Grab & $\mathrm{R}-8$ & PT/Riviera & -- & creek near PT-Z8 \\
\hline 383026077014701 & $6 / 3 / 2008$ & $\mathrm{R}-12 \mathrm{~b}$ & $\begin{array}{l}\text { SW Grab } \\
\text { by PW5 }\end{array}$ & $R-12 b$ & PT/Riviera & -- & creek near PT-Z5 \\
\hline 383026077014702 & $7 / 29 ; 8 / 21 / 2008$ & $\mathrm{CH} \mathrm{Cd} 83$ & $\mathrm{PW}$ D/P & PT-PW5 (PW D/P) & PT/Riviera & 1.0 & creek near PT-Z5 \\
\hline 383023077021201 & $8 / 5 ; 8 / 21 / 2008$ & $\mathrm{CH} \mathrm{Cd} 84$ & $\mathrm{PW}$ D/P & PT-PW8 (PW D/P) & PT/Riviera & 1.0 & creek near PT-Z8 \\
\hline 383027077013204 & $7 / 29 ; 8 / 21 / 2008$ & PT-12 & PW D/P & PT-12 (PW D/P) & $\mathrm{PT}$ & 1.5 & 8240 Riviera Place \\
\hline 383115077005001 & $7 / 29 ; 8 / 21 / 2008$ & PT-26 & $\mathrm{PW}$ D/P & PT-26 (PW D/P) & $\mathrm{PT}$ & 1.0 & Route 6, South side \\
\hline 383027077013204 & $7 / 29 ; 8 / 21 / 2008$ & PT-12 & SW Grab & PT-12 & PT & -- & 8240 Riviera Place \\
\hline 383115077005001 & $7 / 29 ; 8 / 21 / 2008$ & PT-26 & SW Grab & PT-26 & PT & -- & Route 6 , South side \\
\hline 383403076585001 & $7 / 29 ; 8 / 21 / 2008$ & PT-38 & SW Grab & PT-38 & $\mathrm{PT}$ & -- & $\begin{array}{l}\text { Culvert; Washington } \\
\text { Avenue and Sharon } \\
\text { Drive }\end{array}$ \\
\hline 383133077002501 & $7 / 29 ; 8 / 21 / 2008$ & PT-48 & SW Grab & PT-48 & PT & -- & Darly Drive \\
\hline 382714077090201 & $7 / 29 ; 8 / 21 / 2008$ & $\mathrm{~N}-5$ & SW Grab & $\mathrm{N}-5$ & $\mathrm{NC}$ & -- & Friendship Landing \\
\hline
\end{tabular}

\footnotetext{
${ }^{1}$ Sample dates for sites with dialysis and POCIS samplers, respectively, were 7 and 29 days after deployment to allow time for equilibration.
} 
Porewater sampling by passive diffusion techniques in Phase 2 included the use of dialysis bags for inorganic constituents (Ehlke and others, 2004) and POCISs (Alvarez and others, 2004, 2005) for OWCs. Dialysis samplers were made with regenerated cellulose dialysis membrane tubing (18 Angstrom nominal pore size) that was purchased pre-cleaned from the manufacturer (Membrane Filtration Products Inc., San Antonio, Texas). The dialysis samplers were filled with deionized water, placed in a bath of deionized water, and purged with nitrogen gas to remove oxygen for 24 hours prior to placement in the stream-bottom sediments. Laboratory tests have shown that inorganic constituents in the dialysis samplers reach equilibrium within 3 to 7 days, giving concentrations within the samplers that equal the concentrations in the surrounding water (Ehlke and others, 2004). The POCISs are disc-shaped integrative samplers that contain a solidphase sorbent or mixture of sorbents designed to sequester water-soluble (polar or hydrophilic) organic chemicals from water (Alvarez and others, 2004; Tertuliani and others 2008). POCISs were included in the Phase 2 sampling because they (1) can provide samples of the porewater from streambed sediments where the large volumes required for analyses of the wastewater compounds is difficult to obtain from wells, and (2) can concentrate chemicals that may enter the streambed only in trace levels or sporadically with varying hydrologic conditions, and thus provide detections that might not be measured in water grab samples. The POCISs were obtained from Environmental Sampling Technologies (St. Joseph, Missouri) and contained the "generic" mixture of sorbents designed to sequester a wide variety of hydrophilic organic compounds, including many pesticides, pharmaceuticals, and other wastewater contaminants (Alvarez and others, 2004, 2005). Three POCISs were placed at each site and treated as one sample to provide sufficient sorbent material.

The two types of passive diffusion samplers were placed in separate stainless steel holders constructed of vegetable steamer baskets, providing ample openings for flow of water over the samplers while protecting them during deployment and removal from the streambed. The baskets with the diffusion samplers were buried adjacent to each other at a depth of 1.0 to $1.5 \mathrm{ft}$ in the streambed to collect porewater samples. At site PT-48, baskets with diffusion samplers also were attached to a stake and suspended in the surface water to allow comparison of diffusion samplers to grab samples (table 1). The dialysis samplers were kept in the streams for a week before sampling, whereas the POCISs were deployed for 29 days to allow longer time for sequestration of trace organic chemicals.

\section{Sample Collection and Analysis}

The Phase 1 sampling was planned for late summer 2007 because base-flow conditions are best to detect OWCs in streams from a groundwater source (Kolpin and others, 2004). Streamflows in Charles County were below normal in the summer of 2007, however, due to drought conditions.
The surface-water sites that were located along small tributary streams of the Port Tobacco River were dry, or nearly dry, and those located in nontidal areas of Nanjemoy Creek were slowly flowing when sampling was planned to start in September 2007. Only the surface-water sites near and downstream of the La Plata wastewater treatment plant outfall (PT-46 and PT-48) and the sites located in tidal areas (PT-12, PT-25, and PT-35 in the Port Tobacco watershed, and N-1 and N-5 in the Nanjemoy Creek watershed) had fairly stable flow conditions (fig. 2). Phase 1 sampling started during these unusually low streamflow conditions on October 9, 2007, with collection of the Nanjemoy surface-water samples and the Port Tobacco groundwater and porewater samples (table 1). The surface-water sampling of the Port Tobacco sites was delayed until October 30, several days after a heavy rainfall, when information from PTRC volunteers suggested that most of the Port Tobacco sites had returned to near-normal base flows.

For Phase 2, sampling in the Port Tobacco Riviera was planned for late spring 2008 because intermittent streams along the ravines typically become dry during the summer. Surface-water, porewater, and groundwater sampling began on June 3, 2008, but some surface-water and porewater sites were sampled again on June 4, 2008, after a heavy rainfall occurred during the night, providing data on storm effects. For the second Phase 2 sampling event, the dialysis bags and POCISs were deployed in the streambed on July 23, 2008, except at site PT-PW8, where the dialysis bags were deployed on July 29,2008 . One week after deployment, the dialysis samplers were retrieved and sampled for field parameters and inorganic constituents, while surface-water grab samples at the corresponding sites also were sampled for inorganic constituents and OWCs (table 1). The POCISs were retrieved on August 21,2008 , wrapped in aluminum foil, and shipped on ice to Environmental Sampling Technologies (St. Joseph, Missouri) for methanol extraction. The three POCISs from each site were extracted into one vial; these extractions were sent to the USGS National Water Quality Laboratory (NWQL) in Denver, Colorado for custom analysis for the same suite of OWCs as those analyzed in the grab samples, as well as for additional pesticides and pharmaceuticals.

The use of grab samples, rather than integrated crosssectional sampling of surface water as suggested by USGS, was consistent with current sampling methods used by the PTRC and Charles County for bacteria. Collecting USGS samples in the same manner as the bacteria samples was done to facilitate comparisons between the analytes and bacteria counts. Field parameters, including temperature, $\mathrm{pH}$, dissolved oxygen, turbidity, alkalinity, and specific conductance were measured at the sites following USGS protocols (Wilde, variously dated). Field alkalinity samples (reported as calcium carbonate or bicarbonate) were filtered and titrated in the field or in the USGS laboratory within 16 hours of sample collection. To minimize sediment disturbance in the low-flow streams, all surface-water grab samples were collected using 0.25 -in.-diameter Teflon tubing cut into lengths of approximately 10 to $15 \mathrm{ft}$, and attached to $2 \mathrm{ft}$ of silicone rubber 
Table 2. Sample collection and treatment for analysis by the U.S. Geological Survey National Water Quality Laboratory.

[mL, milliliters; $<$, less than]

\begin{tabular}{|c|c|c|}
\hline Analytes & Bottle type & Sample treatment \\
\hline Organic wastewater compounds & 1 liter amber glass & Unfiltered; no sample rinse, chill \\
\hline Major and minor anions & $125 \mathrm{~mL}$ clear polyethylene & $\begin{array}{l}\text { Filtered (rinse first with filtered sample); } \\
\text { chill }\end{array}$ \\
\hline Major cations and metals & $250 \mathrm{~mL}$ acid-washed, clear polyethylene & $\begin{array}{l}\text { Filtered (rinse first with filtered sample); } \\
\text { nitric acid to } \mathrm{pH}<2 \text {; chill }\end{array}$ \\
\hline Laboratory $\mathrm{pH}$ and specific conductance & $100 \mathrm{~mL}$ clear polyethylene & Unfiltered (rinse first with unfiltered sample) \\
\hline $\begin{array}{l}\text { Ammonia, nitrate }+ \text { nitrite, nitrite, orthophosphate } \\
\text { for surface-water samples }\end{array}$ & $125 \mathrm{~mL}$ brown polyethylene & $\begin{array}{l}\text { Filtered (rinse first with filtered sample); } \\
\text { chill }\end{array}$ \\
\hline $\begin{array}{l}\text { Total nitrogen, phosphorus for surface-water } \\
\text { samples }\end{array}$ & $125 \mathrm{~mL}$ clear polyethylene & $\begin{array}{l}\text { Unfiltered (rinse first with unfiltered } \\
\text { sample); sulfuric acid to } \mathrm{pH}<2 \text {; chill }\end{array}$ \\
\hline $\begin{array}{l}\text { Ammonia, nitrate }+ \text { nitrite, nitrite, total nitrogen, } \\
\text { orthophosphate for groundwater and porewater } \\
\text { samples from wells }\end{array}$ & $125 \mathrm{~mL}$ brown plastic & $\begin{array}{l}\text { Filtered (rinse first with filtered sample); } \\
\text { chill }\end{array}$ \\
\hline Ammonia + organic nitrogen & $125 \mathrm{~mL}$ clear polyethylene & Unfiltered; rinse; sulfuric acid; chill \\
\hline Total organic carbon & $125 \mathrm{~mL}$ amber glass & Unfiltered (no sample rinse); chill \\
\hline Total suspended sediment & 250 or $500 \mathrm{~mL}$ clear polyethylene & Unfiltered (rinse first with unfiltered sample) \\
\hline
\end{tabular}

tubing placed in the drive rollers of a peristaltic pump. Clean, new lengths of Teflon and silicone tubing were used at each sampling location. Groundwater and porewater sampling from wells was conducted in a similar manner with a peristaltic pump and tubing. Two to three well volumes of water were withdrawn and discarded to remove stagnant water prior to collecting samples, except only one well volume was purged prior to sampling if the well went dry and took more than 1 hour to recover.

Samples for major ions, selected metals, nutrients, total organic carbon, and OWCs were collected into approved containers, filtered ( 0.45 micron) and preserved if needed, and shipped on ice overnight to NWQL (table 2). Unfiltered water was collected for OWCs, because some of these analytes are hydrophobic and can be associated with both particulate and dissolved organic carbon. The analytical method for OWCs is described by Furlong and others (2001) and Zaugg and others (2006). Analyses for organic carbon and inorganic constituents were conducted at the NWQL following methods and procedures described by American Public Health Association (1998), Fishman (1993), Patton and Truitt (1992, 2000), and Wershaw and others (1987).

\section{Quality Control}

Quality-control samples were collected during each sampling event to provide an estimate of sample contamination and measurement variability associated with the datacollection process (Koterba and others, 1995). Field blank and duplicate samples were collected, preserved, and analyzed using the same methods as those used for the environmental samples. The sample name for the quality-control samples indicates the site at which the samples were collected. For field blank collection for samples collected with a peristaltic pump, clean tubing was attached to the pump after collection of environmental samples at a site, and deionized water was drawn through the tubing (and a clean filter for filtered samples) and into the appropriate sample bottles. Field blanks allow evaluation of potential contamination to samples from the sampling equipment and procedures.

Duplicate samples for samples collected with a peristaltic pump were collected immediately following the environmental samples using the same equipment to provide an indication of the variability of the laboratory analyses and the consistency of sampling techniques. Some variability between 
these sequential duplicate samples may also occur from water movement or other temporal changes in environmental conditions. Using the following equation, a relative percent difference (RPD) was calculated for concentrations between duplicate samples when both values for an analyte had either an estimated or quantified (above the minimum reporting limit) concentration:

$$
R P D=(d / m) \times 100,
$$

where

$\mathrm{d}=$ the difference in concentration between the two duplicate samples for an analyte; and

$\mathrm{m}$ $=$ the mean of the concentrations of the two duplicate samples.
Quality-control samples for the passive diffusion samplers included collection of a POCIS field blank, which was exposed to the air during POCIS deployment and retrieval at one site to evaluate potential contamination from air exposure, and collection of one duplicate dialysis sample. In addition to field quality-control samples, an extraction blank and laboratory blank were collected by Environmental Sampling Technologies to evaluate possible contamination of the POCIS during their processing and extraction before analysis at NWQL. During analysis of OWC samples and POCIS extracts by NWQL, surrogates were added to all environmental and quality-control samples to evaluate water-matrix effects and possible sample-processing errors. Surrogates are compounds that have similar properties to the analytes of interest (and thus behave similarly in the analytical process), but usually are not found in the environment.

Table 3. Concentrations of inorganic constituents and organic carbon detected in field blank samples during Phase 1 and Phase 2 sampling events, Charles County, Maryland, 2007 through 2008.

[E, Estimated value; --, not analyzed $<$, less than; $\mathrm{mg} / \mathrm{L}$, milligrams per liter; $\mu \mathrm{g} / \mathrm{L}$, micrograms per liter. Specific conductance reported as microsiemens per centimeter at 25 degrees Celsius. Detectable concentrations are shown in bold.]

\begin{tabular}{l|l|l|l}
\hline & \multicolumn{2}{|c|}{ Phase 1 } & \multicolumn{1}{c}{ Phase 2 } \\
\hline U.S. Geological Survey site identification number & 383009077013404 & 382714077090201 & 383133077002501 \\
\hline Sample dates & $10 / 09 / 2007$ & $10 / 09 / 2007$ & $07 / 29 / 2008$ \\
\hline Local site name & PT-35 & N-5 & PT-48 \\
\hline Sample type & Field Blank & Field Blank & Field Blank \\
\hline Field name & Blank (PT-35) & Blank (N-5) & Blank (PT-48) \\
\hline & & & \\
\hline Specific conductance, lab, unfiltered & $\mathbf{4}$ & $\mathbf{4}$ & $<8$ \\
\hline Potassium, filtered, $\mathrm{mg} / \mathrm{L}$ & $\mathbf{E . 0 2}$ & $<.02$ & $<.02$ \\
\hline Sodium, filtered, $\mathrm{mg} / \mathrm{L}$ & $\mathbf{E . 1 0}$ & $\mathbf{E . 0 9}$ & $<.12$ \\
\hline Silica, filtered, $\mathrm{mg} / \mathrm{L}$ & $<.2$ & 0.2 & $<.2$ \\
\hline Sulfate, filtered, $\mathrm{mg} / \mathrm{L}$ & $<.18$ & $<.18$ & $<.18$ \\
\hline Copper, filtered, $\mu \mathrm{g} / \mathrm{L}$ & $<2$ & $<2$ & - \\
\hline Ammonia, filtered, $\mathrm{mg} / \mathrm{L}$ as nitrogen & $<.020$ & $\mathbf{E . 0 1 3}$ & $<.020$ \\
\hline Orthophosphate, filtered, $\mathrm{mg} / \mathrm{L}$ as phosphorus & $<.006$ & $\mathbf{E . 0 0 3}$ & $\mathbf{E . 0 0 3}$ \\
\hline Organic carbon, unfiltered, $\mathrm{mg} / \mathrm{L}$ & $\mathbf{E . 2}$ & $<.4$ & $\mathbf{0 . 6}$ \\
\hline
\end{tabular}




\section{Water-Quality Data}

Results of analyses for all the environmental and qualitycontrol samples collected by the USGS are shown in Appendix 1 (Phase 1) and Appendix 2 (Phase 2). Concentrations of inorganic constituents and nutrients, except for some metals, are given in values of milligrams per liter $(\mathrm{mg} / \mathrm{L})$. The OWCs typically occur in very low concentrations and are reported in micrograms per liter $(\mu \mathrm{g} / \mathrm{L})$. A remark code of "<" (less than) is used when a constituent was not detected in a sample. A concentration is reported with a remark code of "E" (to denote "estimated") when a constituent was detected within the method calibration levels but at concentrations outside the reporting levels. Some OWC values may have been coded as "E" because of a failure in some aspect of laboratory quality control, such as low surrogate recoveries, and the sample could not be re-analyzed. A remark code of " $M$ " is used for the OWCs when the presence of a constituent was verified, but the concentration was below the method calibration level.

\section{Field Parameters and Major and Minor Inorganic Constituents}

Field parameters and major and minor inorganic constituents, such as $\mathrm{pH}$, specific conductance, calcium, magnesium, potassium, sodium, iron and manganese, provide information about overall water chemistry and can be used to clarify potential sources of water to the streams and tributaries (Appendixes 1A and 2A). Dissolved copper was measured in Phase 1 sampling (Appendix 1A) because this metal is often derived from plumbing components in home distribution systems. Copper was detected in concentrations equal to or above the detection level $(0.2 \mu \mathrm{g} / \mathrm{L})$ at three surface-water sites, two of which are located at (PT-46) and downstream of (PT-48) the La Plata Wastewater Treatment Plant (WWTP) (Appendix 1A; fig. 2).

Quality-control samples for major and minor inorganic constituents showed only a few compounds detected in the field blanks, and the detected concentrations were estimated because they were below the minimum reporting limit (table $3)$. RPDs were generally less than 5 percent for the major and minor inorganic constituents, although RPDs for iron and fluoride were greater than 10 percent (10.4 and 11.8 percent, respectively) for one set of duplicate samples (table 4).

\section{Nutrients and Organic Carbon}

Nutrients, including nitrogen and phosphorus compounds, and organic carbon may be derived from agricultural sources and domestic animal, wildlife, or human wastes, although they also occur from mineral or vegetation sources. When nutrients reach water bodies, they may contribute to eutrophication, and in high doses, may have human-health effects (Ferrari, 2002). The maximum concentration of nitrate plus nitrite in Phase 1
$(2.38 \mathrm{mg} / \mathrm{L}$ as $\mathrm{N})$ was detected in a surface-water sample collected at site PT-48, which is downstream of the La Plata WWTP (Appendix 1A; fig. 2). The highest ammonia concentrations in Phase 1 were in porewater or groundwater samples, with a maximum of $56 \mathrm{mg} / \mathrm{L}$ detected in a porewater sample from the Port Tobacco River from well CH Cd 58 (PT-PW4) (fig. 3). Orthophosphate and phosphorus concentrations were less than $0.2 \mathrm{mg} / \mathrm{L}$ in all surface-water samples collected in Phase 1, whereas they were greater than $1.0 \mathrm{mg} / \mathrm{L}$ in samples collected from wells CH Cd 55 (PT-Z1A) and CH Cd 58 (PTPW4) in or adjacent to the Port Tobacco River (Appendix 1A; fig. 3). The maximum organic carbon concentration in porewater or groundwater samples in Phase 1 was $26.5 \mathrm{mg} / \mathrm{L}$, which was also measured at well CH Cd 55 (PT-Z1A) adjacent to the Port Tobacco River. Organic carbon concentrations in surfacewater samples in Phase 1 ranged from 3.4 to $28.7 \mathrm{mg} / \mathrm{L}$, with the maximum concentration in sample N-4 in the Nanjemoy River watershed.

In Phase 2, the maximum concentrations of nitrate were detected in surface-water sample R-8 $(3.39 \mathrm{mg} / \mathrm{L}$ as $\mathrm{N})$ and well sample CH Cd 59 (PT-Z5A) $(2.85 \mathrm{mg} / \mathrm{L})$ collected along the ravine sampled in the Port Tobacco Riviera community (Appendix 2A; fig. 3). Of all the samples collected in Phase 2 , the porewater dialysis sample collected at site PT-12 in the Port Tobacco River, which is adjacent to well $\mathrm{CH} \mathrm{Cd} 55$ (PT-Z1A), had the maximum concentrations of ammonia $(11.1 \mathrm{mg} / \mathrm{L})$, orthophosphate $(2.7 \mathrm{mg} / \mathrm{L})$ and organic carbon $(69.9 \mathrm{mg} / \mathrm{L})$. On the basis of laboratory-measured equilibration times, concentrations of inorganic constituents in the dialysis samplers should be equivalent to the average concentrations in the surrounding porewater during the sampler deployment time (Ehlke and others, 2004).

Field blanks collected for quality control had detectable but estimated concentrations of orthophosphate and ammonia, whereas one blank had a quantified concentration $0.6 \mathrm{mg} / \mathrm{L}$ organic carbon (table 3 ). Of the five sets of duplicate surfacewater samples that were collected for quality control, one set had RPDs greater than 10 percent for ammonia, nitrate plus nitrite and organic carbon, and a second set had RPDs greater than 10 percent for ammonia and nitrite (table 4).

\section{Organic Wastewater Compounds}

Concentrations of OWCs detected in the groundwater, porewater, and surface-water grab samples are reported in Appendixes 1B and 2B, respectively, for Phase 1 and Phase 2 , and the POCIS results for porewater and surface-water samples collected in Phase 2 are reported in Appendix 2C. The type and number of OWC detections (including " $\mathrm{O}$ " and "M" coded values) in groundwater and surface-water grab samples, and in POCIS samples during this study are summarized and compared in Appendix 3. Potential uses or sources of detected OWCs are shown in table 5. All OWCs for which analyses were performed but not detected in any of the samples collected in this study are listed in table 6 . 
Table 4. Relative percent difference (RPD) between duplicate samples collected for field parameters, inorganic constituents, and organic carbon during Phase 1 and Phase 2 sampling, Charles County, Maryland, 2007 through 2008.

$[\%$, percent; $\mathrm{mg} / \mathrm{L}$, milligrams per liter; $\mu \mathrm{g} / \mathrm{L}$, micrograms per liter; $\mathrm{g} / \mathrm{L}$, grams per liter; --, not analyzed; NA, not applicable because one or both of the duplicate samples had concentrations below the minimum reporting limit; $\mathrm{SW}$, surface water; $\mathrm{ANC}$, acid-neutralizing capacity as calcium carbonate $\left(\mathrm{CaCO}_{3}\right)$ measured by fixed endpoint ( $\mathrm{pH}$ 4.5) titration; $\mathrm{NH}_{3}+$ org $\mathrm{N}$, ammonia plus organic nitrogen; $\mathrm{NO}_{3}+\mathrm{NO}_{2}$, nitrite-plus-nitrate; $\mathrm{N}$, nitrogen; $\mathrm{P}$, phosphorus. Specific conductance reported as microsiemens per centimeter at 25 degrees Celsius. Detections are shown in bold.]

\begin{tabular}{|c|c|c|c|c|c|}
\hline \multirow[b]{2}{*}{$\begin{array}{l}\text { U.S. Geological Survey site } \\
\text { identification number }\end{array}$} & \multicolumn{3}{|c|}{ Phase 1} & \multicolumn{2}{|c|}{ Phase 2} \\
\hline & 383009077013404 & 383133077002501 & 382714077090201 & 383026077014701 & 38313307002501 \\
\hline Sample dates & $10 / 09 / 2007$ & $10 / 30 / 2007$ & $10 / 09 / 2007$ & $06 / 03 / 2008$ & $07 / 29 / 2008$ \\
\hline Local site name & PT-35 & PT-48 & $\mathrm{N}-5$ & $\mathrm{R}-12 \mathrm{~b}$ & PT-48 \\
\hline \multirow[t]{2}{*}{ Sample type } & SW & SW & SW & SW & SW \\
\hline & RPD \% & RPD \% & RPD \% & RPD \% & RPD \% \\
\hline \multicolumn{6}{|l|}{ Field parameters: } \\
\hline $\mathrm{pH}$, lab, unfiltered, standard units & 2.6 & 0.0 & 0.0 & 2.8 & 1.3 \\
\hline Specific conductance, lab, unfiltered & -- & 0.2 & 0.0 & 0.5 & 0.2 \\
\hline \multicolumn{6}{|l|}{ Major and minor constituents: } \\
\hline Calcium, filtered, $\mathrm{mg} / \mathrm{L}$ & 0.9 & 0.7 & 1.5 & 0.0 & 0.0 \\
\hline Iron, filtered, $\mu \mathrm{g} / \mathrm{L}$ & -- & 10.4 & -- & 0.0 & 2.1 \\
\hline Magnesium, filtered, mg/L & 2.6 & 1.3 & 3.2 & 2.7 & 0.0 \\
\hline Manganese, filtered, $\mu \mathrm{g} / \mathrm{L}$ & 3.4 & 0.8 & 0.2 & 0.3 & 0.5 \\
\hline Potassium, filtered, mg/L & 4.4 & 0.5 & 2.1 & 1.0 & 0.0 \\
\hline Sodium, filtered, mg/L & 0.8 & 0.9 & 0.0 & 0.0 & 0.0 \\
\hline $\mathrm{ANC}$, filtered, $\mathrm{mg} / \mathrm{L} \mathrm{CaCO}_{3}$ & 1.2 & 0.0 & 1.4 & 0.0 & 1.1 \\
\hline Bromide, filtered, mg/L & 0.6 & 0.0 & 3.1 & NA & NA \\
\hline Chloride, filtered, $\mathrm{mg} / \mathrm{L}$ & 0.4 & 0.2 & 1.0 & 0.0 & 1.4 \\
\hline Fluoride, filtered, mg/L & 0.0 & 2.2 & 11.8 & 0.0 & 2.0 \\
\hline Silica, filtered, mg/L & 0.0 & 0.0 & 2.2 & 3.3 & 0.0 \\
\hline Sulfate, filtered, $\mathrm{mg} / \mathrm{L}$ & 0.8 & 0.1 & 1.0 & 0.5 & 1.8 \\
\hline Copper, filtered, $\mu \mathrm{g} / \mathrm{L}$ & -- & 0.0 & -- & NA & NA \\
\hline \multicolumn{6}{|l|}{ Nutrients and organic carbon: } \\
\hline $\mathrm{NH}_{3}+$ org $\mathrm{N}$, unfiltered, $\mathrm{g} / \mathrm{L}$ as $\mathrm{N}$ & 6.7 & 4.5 & 5.1 & 5.7 & -- \\
\hline Ammonia, filtered, $\mathrm{mg} / \mathrm{L}$ as $\mathrm{N}$ & 16.9 & 1.5 & 12.7 & NA & 0.0 \\
\hline $\mathrm{NO}_{3}+\mathrm{NO}_{2}$, filtered, $\mathrm{mg} / \mathrm{L}$ as $\mathrm{N}$ & 15.4 & 1.3 & 0.0 & NA & 2.6 \\
\hline Nitrite, filtered, $\mathrm{mg} / \mathrm{L}$ as $\mathrm{N}$ & 0.0 & 0.0 & 18.2 & NA & 0.0 \\
\hline Total nitrogen, unfiltered, $\mathrm{mg} / \mathrm{L}$ & 3.6 & 4.3 & 2.2 & NA & 0.8 \\
\hline Orthophosphate, filtered, $\mathrm{mg} / \mathrm{L}$ as $\mathrm{P}$ & 5.4 & 3.3 & 3.9 & NA & 4.2 \\
\hline Phosphorus, unfiltered, mg/L & 5.7 & 3.9 & 0.9 & NA & 0.5 \\
\hline Organic carbon, unfiltered, mg/L & 13.7 & 3.3 & 1.4 & 8.3 & 4.5 \\
\hline
\end{tabular}


Table 5. Potential uses or sources of organic wastewater compounds that were detected in groundwater and surface-water grab samples and in Polar Organic Chemical Integrative Sampler (POCIS) samples, Port Tobacco River and Nanjemoy Creek watersheds, Charles County, Maryland, 2007 through 2008.

[\%, percent; PAHs, polycyclic aromatic hydrocarbons]

\begin{tabular}{|c|c|c|}
\hline Compound & Uses or sources ${ }^{1}$ & Compound class ${ }^{2}$ \\
\hline \multicolumn{3}{|c|}{ Grab samples } \\
\hline 1-Methylnaphthalene & $\begin{array}{l}\text { Wood burning, fossil fuel; tar, asphalt; } 2-5 \% \text { of gasoline, diesel } \\
\text { fuel, or crude oil }\end{array}$ & PAHs \\
\hline 2,6-Dimethylnaphthalene & $\mathrm{PAH}$; in diesel/kerosene (trace in gasoline) & PAHs \\
\hline 2-Methylnaphthalene & $2-5 \%$ of gasoline, diesel fuel, or crude oil & PAHs \\
\hline 3-Methyl-1H-indole (skatol) & Fragrance, stench in feces and coal tar & Fragrance/Flavorants \\
\hline 3-tert-Butyl-4-hydroxyanisole (BHA) & Antioxidant, food preservative & Other Compounds \\
\hline 4-Cumylphenol & Nonionic detergent metabolite & Detergent Degradates \\
\hline 4-Nonylphenol (sum of all isomers) & Nonionic detergent metabolite & Detergent Degradates \\
\hline $\begin{array}{l}\text { Acetyl hexamethyl tetrahydro naphthalene } \\
\text { (AHTN or tonalide) }\end{array}$ & Musk fragrance (a naphthalene) & Fragrance/Flavorants \\
\hline Anthracene & PAH; Wood preservative, component of tar,diesel, or crude oil & PAHs \\
\hline 9,10-Anthraquinone & Textile dye, seed treatment, bird repellant & Pesticides \\
\hline Atrazine & Selective triazine herbicide & Pesticides \\
\hline Benzo[a]pyrene & Regulated PAH, used in cancer research & PAHs \\
\hline Benzophenone & Fixative for perfumes and soaps & Other Compounds \\
\hline beta-Sitosterol & Plant sterol & Sterols \\
\hline beta-Stigmastanol & Plant sterol & Sterols \\
\hline Cotinine & Nicotine metabolite & Other Compounds \\
\hline N,N-Diethyltoluamide (DEET) & Mosquito repellent, insecticide ingredient & Pesticides \\
\hline 4-tert-Octylphenol diethoxylate & Nonionic detergent metabolite & Detergent Degradates \\
\hline Diethyl phthalate & Plasticizer for polymers and resins & Plasticizer \\
\hline Diethylhexyl phthalate & Plasticizer for polymers and resins & Plasticizer \\
\hline Fluoranthene & PAH, component of coal tar and asphalt & PAHs \\
\hline Galaxolide (HHCB) & Musk fragrance & Fragrance/Flavorants \\
\hline Indole & Pesticide inert ingredient, fragrance in coffee & Pesticides \\
\hline Isoborneol & Fragrance in perfumery, in disinfectants & Other Compounds \\
\hline Isophorone & Solvent for lacquer, plastic, oil, silicon, resin & Other Compounds \\
\hline Methyl salicylate & Liniment, food, beverage,UV-absorbing lotion & Other Compounds \\
\hline
\end{tabular}


Table 5. Potential uses or sources of organic wastewater compounds that were detected in groundwater and surface-water grab samples and in Polar Organic Chemical Integrative Sampler (POCIS) samples, Port Tobacco River and Nanjemoy Creek watersheds, Charles County, Maryland, 2007 through 2008.-Continued

[\%, percent; PAHs, polycyclic aromatic hydrocarbons]

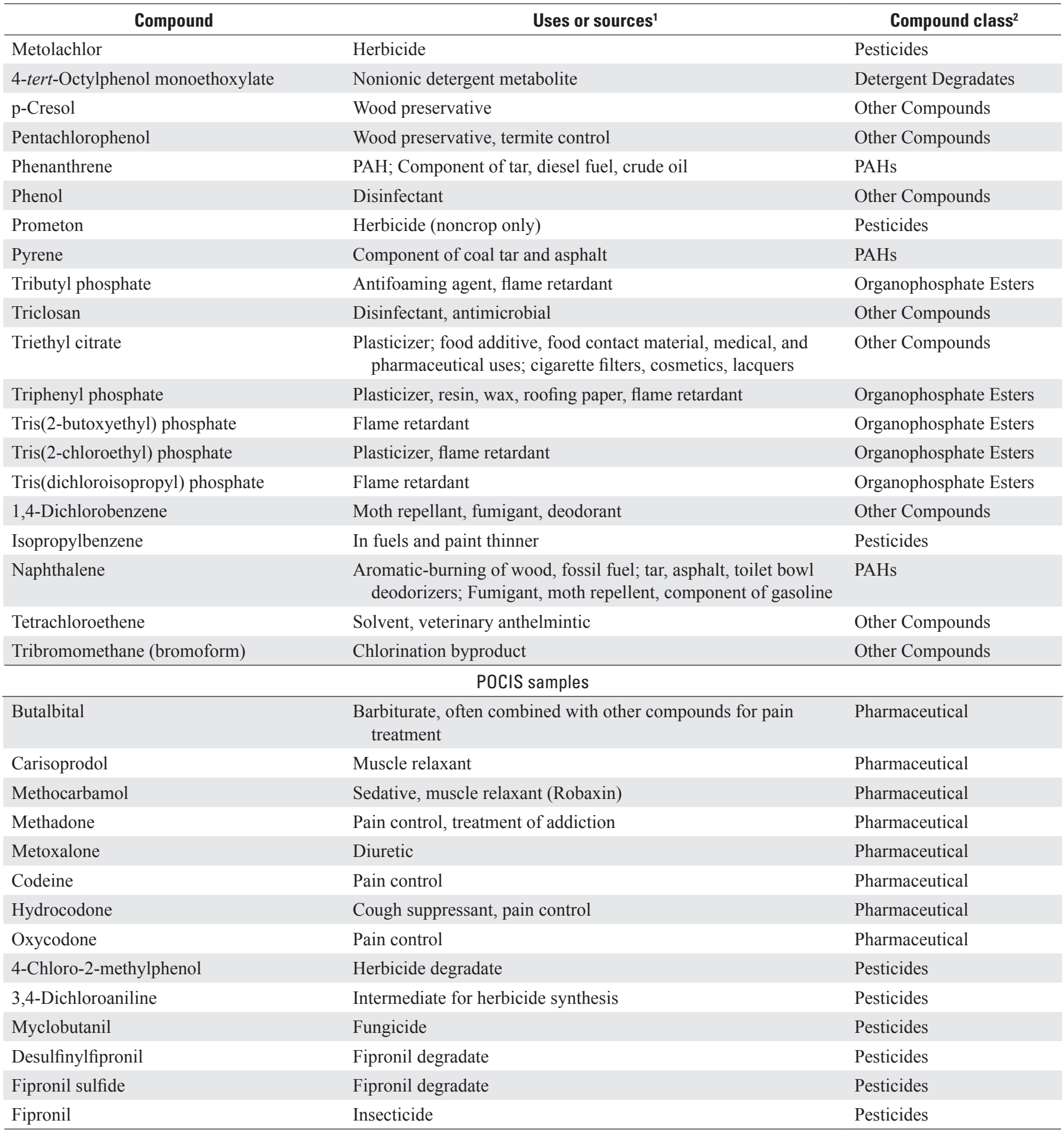

${ }^{1}$ Possible uses for the Schedule 4433 compounds from Zaugg and others (2006) and Gibs and others (2007).

${ }^{2}$ Compound class designation from Phillips and Chalmers (2009). 
Table 6. Organic wastewater compounds that were analyzed but not detected in groundwater and surface-water grab samples, or in Polar Organic Chemical Integrative Sampler (POCIS) samples collected in the Port Tobacco River and Nanjemoy Creek watersheds, Charles County, Maryland, 2007 through 2008.

\begin{tabular}{|c|c|c|}
\hline \multicolumn{3}{|c|}{ Grab samples } \\
\hline 4-n-Octylphenol & \multicolumn{2}{|l|}{ d-Limonene } \\
\hline BDE 47, (2,2',4,4'-Tetrabromodiphenyl Ether) & \multicolumn{2}{|c|}{ 4-Nonylphenol diethoxylate (sum of all isomers) } \\
\hline Bromacil & \multicolumn{2}{|c|}{ Isoquinoline } \\
\hline Carbaryl & \multicolumn{2}{|l|}{ Menthol } \\
\hline Chlorpyrifos & \multicolumn{2}{|l|}{ Metalaxyl } \\
\hline Diazinon & \multicolumn{2}{|c|}{ 4-Nonylphenol monoethoxylate (sum of all isomers) } \\
\hline Chloroxylenol & Diazinon & 2-chloro-2,6-diethylacetanilide \\
\hline Phendimetrizine & Terbufos & Dimethoate \\
\hline Chlorpheniramine & Pronamide & Prometon \\
\hline Cocaine & Fonofos & Simazine \\
\hline 2,6-diethylaniline & Metribuzin & Terbufos-O-analog sulfone \\
\hline Tebuthiuron & Methyl parathion & Metolachlor \\
\hline Phorate oxon & Alachlor & Chlorpyrifos \\
\hline Trifluralin & Prometryn & Dacthal \\
\hline Benfluralin & Metalaxyl & Pendimethalin \\
\hline Dicrotophos & Carbaryl & Isofenphos \\
\hline Deethylatrazine & Malathion & Methidathion \\
\hline Phorate & Chlorpyrifos oxys & \\
\hline
\end{tabular}


Table 7. Organic wastewater compounds detected in field blank samples during Phase 1 and Phase 2 sampling events, Charles Charles County, Maryland, 2007 through 2008.

[All analyses were performed on unfiltered samples, and results are reported in micrograms per liter, unless otherwise noted; M, measured as present but not quantified; $<$, less than. Detections are shown in bold.]

\begin{tabular}{l|l|l|l|l}
\hline & \multicolumn{2}{|c|}{ Phase 1 } & & Phase 2 \\
\hline $\begin{array}{l}\text { U.S. Geological Survey site } \\
\text { identification number }\end{array}$ & 383009077013404 & 382714077090201 & 383026077014701 & 383133077002501 \\
\hline Sample dates & $10 / 09 / 2007$ & $10 / 09 / 2007$ & $06 / 03 / 2008$ & $07 / 29 / 2008$ \\
\hline Local site name & PT-35 & N-5 & R-12b & PT-48 \\
\hline Sample type & Field Blank & Field Blank & Field Blank & Field Blank \\
\hline Field name & Blank (PT-35) & Blank (N-5) & Field Blank (R-12b) & Field Blank (PT-48) \\
\hline & & & & $<.2$ \\
\hline Acetophenone & $<2$ & $\mathbf{0 . 6}$ & $<.2$ & $<.2$ \\
\hline N,N-Diethyltoluamide (DEET) & $\mathbf{M}$ & $<.2$ & $<.2$ & $<.2$ \\
\hline Naphthalene & $<.2$ & $\mathbf{M}$ & $<.2$ & $\mathbf{0 . 8}$ \\
\hline Diethyl phthalate & & $<.2$ & & $<$ \\
\hline
\end{tabular}

The POCISs are integrative samplers rather than equilibrium samplers like the dialysis samplers, and the uptake of hydrophilic organic compounds on the POCISs would vary due to exposure time, exposure conditions within the streambed (including velocity-turbulence at the membrane surface, temperature, and membrane biofouling), and each compound's specific chemical properties (Tertuliani and others 2008). Because the uptake rates of the individual compounds are unknown, the results for the POCISs are reported as nanograms of chemical sequestered (and subsequently extracted with methanol) per methanol extract, which was a composite extraction from each of the three POCIS membranes placed at each site. In addition, all concentrations for the POCISs are considered to be estimates because these were a custom analysis for which a method validation has not been completed by the USGS NWQL. The POCIS data are useful for comparison of the relative detections among the POCISs and of the relative detections in the porewater from the POCISs to the porewater and surface-water grab samples.

The greatest number of OWCs were detected in the samples collected in the Port Tobacco River watershed in 2007 (Phase 1) compared to 2008 (Phase 2). The number of
OWCs detected in well samples (groundwater or porewater) in 2007 ranged from 4 to 27, whereas the number of compounds detected in the surface-water samples ranged from 3 to 31 (Appendix 3). The maximum number of OWC detections in the groundwater or porewater samples was at well PTZ-4A (CH Cd 57), whereas the maximum detections in the surface-water samples were at sites PT-46 and PT-48, respectively, at and downstream of the La Plata WWTP outfall (fig. 2; Appendix 3). The number of OWCs detected in the POCIS samples that were collected in 2008 ranged from 1 to 17, with the maximum measured at site PT-48 (Appendix 3). Most of the surface-water samples collected in the Nanjemoy Creek watershed had fewer detected OWCs (one to eight) than the samples collected in the Port Tobacco River watershed (Appendix 3).

Field blanks collected for quality control had four OWCs detected in Phase 1 and one OWC detected in Phase 2 (table 7). RPDs in duplicate samples analyzed for OWCs were mostly 0 percent because the same OWCs were often measured in both samples either qualitatively ("M" coded samples) or quantitatively (table 8). 
Table 8. Relative percent difference (RPD) between duplicate samples collected for organic wastewater compounds during Phase 1 and Phase 2 sampling, Charles County, Maryland, 2007 through 2008.

[All analyses were performed on unfiltered samples. \%, percent; Q, quantified; E, Estimated, M, measured as present but not quantified; <, less than; SW, surface water; AHTN, Acetyl hexamethyl tetrahydro naphthalene; HHCB, Hexahydrohexamethyl cyclopentabenzopyran]

\begin{tabular}{|c|c|c|}
\hline \multicolumn{3}{|c|}{ Phase 1} \\
\hline \multirow{5}{*}{$\begin{array}{l}\text { U.S. Geological Survey site } \\
\text { identification number } \\
\text { Sample date } \\
\text { Local site name } \\
\text { Sample type }\end{array}$} & \multicolumn{2}{|c|}{383133077002501} \\
\hline & \multicolumn{2}{|c|}{$10 / 30 / 2007$} \\
\hline & \multicolumn{2}{|l|}{ PT-48 } \\
\hline & \multicolumn{2}{|l|}{ SW } \\
\hline & RPD $\%$ & Code \\
\hline 3,4-Dichlorophenyl isocyanate & 9 & $\mathrm{E}$ \\
\hline 3-Methyl-1H-indole (skatol) & 0 & M \\
\hline 5-Methyl-1H-benzotriazole & 0 & M \\
\hline AHTN, or tonalide & 0 & Q \\
\hline 9,10-Anthraquinone & 0 & M \\
\hline Benzophenone & 67 & $\mathrm{E}$ \\
\hline Cholesterol & 0 & M \\
\hline Cotinine & 0 & M \\
\hline N,N-Diethyltoluamide (DEET) & 0 & Q \\
\hline Diethyl phthalate & 133 & $\mathrm{E}$ \\
\hline Fluoranthene & 0 & M \\
\hline Galaxolide, or HHCB & 0 & M \\
\hline Indole & 0 & M \\
\hline p-Cresol & 0 & M \\
\hline Pentachlorophenol & 0 & M \\
\hline Prometon & 0 & M \\
\hline Pyrene & 0 & M \\
\hline Tributyl phosphate & 0 & $\mathrm{E}$ \\
\hline Triclosan & 0 & M \\
\hline Triethyl citrate & 0 & $\mathrm{E}$ \\
\hline Triphenyl phosphate & 0 & $\mathrm{E}$ \\
\hline Tris(2-butoxyethyl) phosphate & 0 & $\mathrm{E}$ \\
\hline Tris(2-chloroethyl) phosphate & 29 & Q \\
\hline Tris(dichloroisopropyl) phosphate & 0 & Q \\
\hline 1,4-Dichlorobenzene & 0 & M \\
\hline
\end{tabular}

\begin{tabular}{|c|c|c|}
\hline \multicolumn{3}{|c|}{ Phase 1} \\
\hline $\begin{array}{l}\text { U.S. Geological Survey site } \\
\text { identification number }\end{array}$ & \multicolumn{2}{|c|}{383009077013404} \\
\hline Sample date & \multicolumn{2}{|l|}{$10 / 09 / 2007$} \\
\hline Local site name & \multicolumn{2}{|l|}{ PT-35 } \\
\hline Sample type & \multicolumn{2}{|l|}{ SW } \\
\hline & RPD \% & Code \\
\hline 2,6-Dimethylnaphthalene & 0 & M \\
\hline Atrazine & 0 & $\mathrm{E}$ \\
\hline Cholesterol & 40 & E \\
\hline Fluoranthene & 0 & M \\
\hline Isophorone & 0 & M \\
\hline Phenanthrene & 0 & M \\
\hline Pyrene & 0 & M \\
\hline
\end{tabular}

\begin{tabular}{|l|cc|}
\hline \multicolumn{2}{|c|}{ Phase 1 } \\
\hline $\begin{array}{l}\text { U.S. Geological Survey site } \\
\text { identification number }\end{array}$ & 382714077090201 \\
Sample date & $10 / 09 / 2007$ \\
Local site name & N-5 \\
Sample type & SW & \\
\hline & RPD \% & Code \\
\hline Atrazine & 40 & Q \\
Cholesterol & 0 & E \\
N,N-Diethyltoluamide (DEET) & 0 & M \\
Isophorone & 0 & M \\
\hline
\end{tabular}

\begin{tabular}{|l|cc|}
\hline \multicolumn{2}{|c|}{ Phase 2 } \\
\hline $\begin{array}{l}\text { U.S. Geological Survey site } \\
\text { identification number }\end{array}$ & 383133077002501 \\
Sample date & $07 / 29 / 2008$ \\
Local site name & PT-48 \\
Sample type & SW & \\
\hline & RPD \% & Code \\
\hline 3-Methyl-1H-indole (skatol) & 0 & M \\
AHTN, or tonalide & 0 & E \\
Benzophenone & 0 & E \\
Galaxolide, or HHCB & 29 & Q \\
Triethyl citrate & 0 & E \\
Tris(2-butoxyethyl) phosphate & 0 & E \\
Tris(2-chloroethyl) phosphate & 29 & Q \\
Tris(dichloroisopropyl) phosphate & 29 & Q \\
\hline
\end{tabular}




\section{Summary}

The U.S. Geological Survey performed two phases of water-quality sampling in October 2007 and June-August 2008 in the Port Tobacco River and Nanjemoy Creek watersheds in Charles County, Maryland to provide data that could assist in determining the sources of historically high enterococci bacteria in the main surface-water bodies and tributaries in these watersheds. Surface-water samples for major and minor inorganic constituents, nutrients, and organic wastewater compounds were collected throughout the Port Tobacco River and Nanjemoy Creek watersheds, as well as focused groundwater, porewater, and surface-water sampling in the Port Tobacco Riviera community to provide more extensive water-quality data in a residential community that uses domestic septic systems. Groundwater and porewater sampling sites in the Port Tobacco Riviera were located in and along an intermittent stream and the Port Tobacco River. For Phase 1, waterquality data were reported for 10 surface-water sites within the Port Tobacco River watershed, 5 surface-water sites within the Nanjemoy Creek watershed, and 6 groundwater or porewater wells located in the Port Tobacco Riviera community. For Phase 2, water-quality data included paired surface-water and porewater samples collected at selected locations in the Port Tobacco Riviera community and throughout the Port Tobacco River watershed, including downstream of an outfall from a wastewater treatment plant. Porewater data include samples collected either from shallow wells or by passive diffusion sampling techniques. Data from quality-control samples (field blanks and duplicate samples) also are presented. Summaries are provided of the type and number of organic wastewater compounds detected in surface-water, groundwater, and porewater samples and of their potential uses or sources.

\section{Acknowledgments}

Thanks are extended to the Charles County Department of Health and the Port Tobacco River Conservancy, Inc., for contributing financial support to this study, helping with field logistics, and providing knowledge of the study area. The time and effort contributed by multiple volunteers from the Port Tobacco River Conservancy, Inc., and the Nanjemoy Conservancy to coordinate their bacteria sample collection with USGS water-quality sampling is acknowledged and appreciated. We are grateful to the residents of Charles County who allowed us access to their property. The authors would also like to thank USGS personnel who contributed to the preparation, collection, documentation, and processing of the analytical samples, including Elizabeth Marchand, David Brower, Ben Smith, Brenda Majedi, Joe Sullivan, and Brandon Fleming.

\section{References Cited}

Alvarez, D.A., Petty, J.D., Huckins, J.N., Jones-Lepp, T.L., Getting, D.T., Goddard, J.P., and Manahan, S.E., 2004, Development of a passive, in situ, integrative sampler for hydrophilic organic contaminants in aquatic environments: Environmental Toxicology and Chemistry, v. 23, no. 7, p. 1,640-1,648.

Alvarez, D.A., Stackelberg, P.E., Petty, J.D., Huckins, J.N., Furlong, E.T., Zaugg, S.D., and Meyer, M.T., 2005, Comparison of a novel passive sampler to standard watercolumn sampling for organic contaminants associated with wastewater effluents entering a New Jersey stream: Chemosphere, v. 61, no. 5, p. 610-622.

American Public Health Association, 1998, Standard methods for the examination of water and wastewater (20th ed.): Washington, D.C., American Public Health Association, American Water Works Association, and Water Environment Federation, p. 3-37-3-43.

Ator, S.W., Denver, J.M. and Brayton, M.J., 2005, Hydrologic and geochemical controls on pesticide and nutrient transport to two streams on the Delmarva Peninsula: U.S. Geological Survey Scientific Investigations Report 2004-5051, 34 p.

Clark, W.B., and Martin, G.C., 1901, The Eocene deposits of Maryland, in Clark, W.B., and others, Eocene: Maryland Geological Survey Systematic Report, 331 p.

Curtin, S.E., Bringman, D.A., and Marchand, E.H., 2006, Water resources data - Maryland, Delaware, and Washington, D.C., Water Year 2005: Volume 2. Groundwater data: U.S. Geological Survey Water-Data Report MD-DE-DC-05-2, 574 p.

Ehlke, T.A., Imbrigiotta, T.E., and Dale, J.M., 2004, Laboratory comparison of polyethylene and dialysis membrane diffusion samplers: Ground Water Monitoring and Remediation, v. 24, no. 1, p. 53-59.

Erickson, B., 2002, Analyzing the ignored environmental contaminants: Environmental Science and Technology, v.36, no. 7 ,p. 140-145.

Ferrari, M.J., 2002, Occurrence and distribution of selected contaminants in public drinking-water supplies in the surficial aquifer in Delaware: U.S. Geological Survey Open-File Report 01-327, 62 p.

Fishman, M.J., ed., 1993, Methods of analysis by the U.S. Geological Survey National Water Quality LaboratoryDetermination of inorganic and organic constituents in water and fluvial sediments: U.S. Geological Survey OpenFile Report 93-125, 217 p. 
Furlong, E.T., Anderson, B.D., Werner, S.L., Soliven, P.P., Coffey, L.J., and Burkhardt, M.R., 2001, Methods of analysis by the U.S. Geological Survey National Water Quality Laboratory-Determination of pesticides in water by graphitized carbon-based solid-phase extraction and highperformance liquid chromatography/mass spectrometry: U.S. Geological Survey Water-Resources Investigations Report 01-4134, 73 p.

Gibs, J., Stackelberg, P.E., Furlong, E.T., Meyer, M., Zaugg, S.D., and Lippincott, R.L., 2007, Persistence of pharmaceuticals and other organic compounds in chlorinated drinking water as a function of time: Science of the Total Environment, v. 373, no. 1, p. 240-249.

Hyer, K.E., 2007, A multiple-tracer approach for identifying sewage sources to an urban stream system: U.S. Geological Survey Scientific Investigations Report 2006-5317, 89 p.

Kolpin, D.W., Furlong, E.T., Meyer, M.T., Thurman, E.M., Zaugg, S.D., Barber, L.B., and Buxton, H.T., 2002, Pharmaceuticals, hormones, and other organic wastewater contaminants in U.S. streams, 1999-2000: A national reconnaissance: Environmental Science and Technology, v. 36 , no. 6 , p. $1,202-1,211$.

Kolpin, D.W., Skopec, M., Meyer, M.T., Furlong, E.T., and Zaugg, S.D., 2004, Urban contribution of pharmaceuticals and other organic wastewater contaminants to streams during differing flow conditions: Science of the Total Environment, v. 328, nos. 1-3, p. 119-130.

Koterba, M.T., Wilde, F.D., and Lapham, W.W., 1995, Groundwater data-collection protocols and procedures for the National Water-Quality Assessment ProgramCollection and documentation of water-quality samples and related data: U.S. Geological Survey Open-File Report 95-399, $113 \mathrm{p}$.

Krantz, D.E., and Powars, D.S., 2000, Hydrogeologic setting and potential for denitrification in ground water, Coastal Plain of Southern Maryland: U.S. Geological Survey OpenFile Report 00-4051, 19 p.

McCartan, L., 1989, Geologic map of Charles County, Maryland: Maryland Geological Survey, 1 sheet, scale 1:62,500 (available at http://www.mgs.md.gov/esic/ publications/pubcatdigicnty.html).

Miller, C.V., Weyers, H.S., Blazer, V.S., and Freeman, M.E., 2006, Chemical and ecological health of White Sucker (Catostomus commersoni) in Rock Creek Park, Washington, D.C., 2003-2004: U.S. Geological Survey Scientific Investigations Report 2006-5140, 37 p.
Patton, C.J., and Truitt, E.P., 1992, Methods of analysis by the U.S. Geological Survey National Water Quality Laboratory-Determination of total phosphorus by a Kjeldahl digestion method and an automated colorimetric finish that includes dialysis: U.S. Geological Survey OpenFile Report 92-146, 39 p.

Patton, C.J., and Truitt, E.P., 2000, Methods of analysis by the U.S. Geological Survey National Water Quality Laboratory-Determination of ammonium plus organic nitrogen by a Kjeldahl digestion method and an automated photometric finish that includes digest cleanup by gas diffusion: U.S. Geological Survey Open-File Report 00-170, $31 \mathrm{p}$.

Phillips, P., and Chalmers, A., 2009, Wastewater effluent, combined sewer overflows, and other sources of organic compounds to Lake Champlain: Journal of the American Water Resources Association, v. 45, no. 1, p. 45-57.

Port Tobacco River Conservancy, Inc., 2008, Water quality results (available as a spreadsheet) accessed January 5, 2010 at http://porttobaccoriver.org/ProjectsWaterMonitoring. html.

Soeder, D.J., Raffensperger, J.P., and Nardi, M.R. 2007, Effects of withdrawals on groundwater levels in Southern Maryland and the adjacent Eastern Shore, 1980-2005: U.S. Geological Survey Scientific Investigations Report 2007-5249, 82 p.

Tertuliani, J.S., Alvarez, D.A., Furlong, E.T., Myer, M.T., Zaugg, S.D., and Koltun, G.F., 2008, Occurrence of organic wastewater compounds in the Tinkers Creek watershed and two other tributaries to the Cuyahoga River, Northeast Ohio: U.S. Geological Survey Scientific Investigations Report 2008-5173, 60 p.

U.S. Census Bureau, 2008, Population finder, 2006 estimate for La Plata town, Maryland, accessed January 5, 2010 at http://www.census.gov/.

Wershaw, R.L., Fishman, M.J., Grabbe, R.R., and Lowe, L.E., eds., 1987, Methods for the determination of organic substances in water and fluvial sediments: U.S. Geological Survey Techniques of Water-Resources Investigations, book 5, chap. A3, $80 \mathrm{p}$.

Wilde, F.D., ed., chapter sections variously dated, Field measurements: U.S. Geological Survey Techniques of Water-Resources Investigations, book 9, chap. A6, accessed January 26, 2010 at http://pubs.water.usgs.gov/twri9A6/.

Zaugg, S.D., Smith, S.G., and Schroeder, M.P., 2006, Determination of wastewater compounds in whole water by continuous liquid-liquid extraction and capillary-column gas chromatography/mass spectrometry: U.S. Geological Survey Techniques and Methods, book 5, chap. B4, 30 p. 

Prepared by USGS West Trenton Publishing Service Center. Edited by Valerie M. Gaine.

Graphics and layout by Timothy W. Auer.

For additional information, contact:

Director, MD-DE-DC Water Science Center

U.S. Geological Survey

5522 Research Park Drive

Baltimore, MD 21228

or visit our Web site at: http://md.water.usgs.gov 
